\title{
Pemberian Tepung Singkong yang Ditambahkan Isoamilase dalam Pakan terhadap Performa Ayam Broiler
}

\author{
Cassava Meal Feeding with Isoamilase Addition in Rations on Broiler Perform
}

M Rahmadani*, W Hermana, Nahrowi

Corresponding email: mardiahrahmadani123@gmail.com

Departemen Ilmu Nutrisi dan Teknologi Pakan Fakultas Peternakan IPB University, J. Agatis Kampus IPB Dramaga, Bogor, Indonesia

Submitted: $4^{\text {th }}$ January 2021 Accepted : $30^{\text {th }}$ March 2021

\section{ABSTRACT}

Cassava has the potential use to replace corn as an energy source in poultry feed. However, the level of substitution is not optimal because of the difference ratio of amylose and amylopectin in maize and cassava. This study aimed to examine the effect of cassava flour with addition of isoamylase as a corn substitute in the ration on the performance of broilers. The material used in this study was 150 male day-old chicken broiler which were randomly divided into 3 treatments and 5 replications. The treatments were P0: $50 \%$ corn in the ration (control); P1: Substitution of $50 \%$ of corn by cassava flour; P2: Substitution of $50 \%$ of corn by cassava flour which contained $0.14 \%$ isoamylase. The variables measured were feed intake, body weight, weight gain, feed conversion ratio, income over feed and chick cost and mortality rate. Data from the complete randomized design were analyzed using Analysis of Variance, the significant results between the treatments were obtained by Duncan Multiple Range Test. The results showed that the substitution of corn by cassava flour without and with $0.14 \%$ isoamylase was not significantly affect final body weight, body weight gain, feed intake and feed conversion ratio. The most profitable Income over feed cost obtained was the treatment of P2 that is $\mathrm{Rp} 6,543.50$. It can be concluded that the corn substitution by cassava flour without and with addition of $0.14 \%$ isoamylase was able to produce the same performance as broiler chickens fed with corn in the ration for five weeks of the study.

Key words: broiler, isoamylase, cassava flour, performance

\section{ABSTRAK}

Singkong berpotensi menggantikan jagung sebagai sumber energi dalam pakan unggas. Namun, tingkat substitusi tidak optimal karena perbedaan rasio amilosa dan amilopektin pada jagung dan singkong. Penelitian ini bertujuan untuk menguji pengaruh tepung singkong yang ditambahkan isoamilase sebagai pengganti jagung dalam ransum terhadap performan ayam broiler. Penelitian ini menggunakan 150 day old chicken broiler jantan yang dibagi secara acak menjadi 3 perlakuan dan 5 ulangan. Perlakuan yaitu P0: 50\% jagung dalam ransum (kontrol); P1: Substitusi 50\% jagung dengan tepung singkong; P2: Substitusi 50\% jagung dengan tepung singkong yang ditambahkan $0,14 \%$ isoamilase. Variabel yang diukur adalah konsumsi pakan, bobot badan, pertambahan bobot badan, konversi pakan, income over feed cost dan mortalitas. Data penelitian dianalisis menggunakan Analysis of Variance, perbedaan yang nyata antar perlakuan diuji dengan Duncan Multiple Range Test. Hasil penelitian menunjukkan bahwa substitusi jagung dengan tepung singkong tanpa dan dengan ditambahkan 0,14\% isoamilase tidak mempengaruhi bobot badan akhir, pertambahan bobot badan, konsumsi pakan dan konversi pakan. Income over feed and chick cost diperoleh hasil yang menguntungkan untuk perlakuan pakan menggunakan tepung singkong yaitu sebesar Rp 6.543,50 kg-1. Dapat disimpulkan bahwa pemberian tepung singkong tanpa dan dengan penambahan 0,14\% isoamilase mampu menghasilkan performa yang sama seperti ayam broiler yang diberi pakan jagung dalam ransum selama lima minggu penelitian

Kata kunci: ayam broiler, isoamilase, tepung singkong, performa 


\section{PENDAHULUAN}

Komoditas jagung mempunyai fungsi multiguna, meliputi pangan (food), pakan (feed), bahan bakar (fuel) dan bahan baku industri (fiber). Jagung dalam pakan khususnya ternak unggas berperan sebagai sumber energi yang dominan dengan persentase penggunaan dalam ransum berkisar 50\%-60\%. Pemenuhan kebutuhan jagung nasional masih memiliki kendala, dimana kebutuhan jagung nasional meningkat sebesar $6,6 \%$ per tahun, sedangkan produksinya hanya meningkat 4,3\% per tahun (Aldillah, 2018). Sehingga kegiatan mengimpor jagung dari negara lain masih terus dilakukan dan memberikan dampak pada harga jagung domestik yang dua kali lebih mahal dibanding harga internasional (Freddy \& Gupta, 2018). Perbedaan harga ini disebabkan lokasi produksi jagung lokal cenderung jauh dari konsumen, sedangkan logistik di Indonesia belum mendukung untuk penyediaan di sentra konsumen. Oleh karena itu, perlu adanya upaya untuk menekan biaya pakan salah satunya adalah mengganti sebagian jagung dengan bahan alternatif lain yang lebih murah dan mudah diperoleh serta tidak menimbulkan efek buruk pada ayam.

Sumber energi yang berpotensi untuk menggantikan jagung adalah singkong. Produksi singkong nasional menurut Kementan (2018) sebesar 19,34 juta ton., tetapi tingkat keberhasilan singkong sebagai pakan substitusi jagung terbatas, karena tingginya kadar sianida, serat, tidak mengandung $\beta$-caroten, rendah protein dan energi. Selain itu, perbandingan kandungan pati singkong dan jagung juga menjadi faktor pembatas penggunaannya dalam ransum. Pati singkong mengandung 23,92\% amilosa dan 76,08\% amilopektin (Puspita, 2019). Nilai ini berbeda dengan pati jagung yang memiliki $27 \%$ amilosa dan 73\% amilopektin (Dei, 2017). Kiatponglarp \& Tongta (2007) memperoleh tingkat pati resisten yang tinggi pada singkong karena terdiri dari 82,85\% amilopektin dengan asosiasi cabang 5,79\% dan amilosa $17,25 \%$ dengan asosiasi cabang 0,48\%. Hal ini menyebabkan pati singkong sulit dicerna dan dimanfaatkan oleh unggas.

Upaya meningkatkan kandungan amilosa pada tepung singkong dilakukan dengan penambahan enzim, sehingga rasio amilosa dan amilopektin singkong mendekati rasio amilosa dan amilopektin jagung. Salah satu enzim yang dapat digunakan adalah isoamilase. Enzim ini mampu menghidrolisis rantai cabang $\alpha-1,6$ dalam amilopektin, sehingga meningkatkan jumlah amilosa dan produktivitas ayam broiler. Puspita (2019), menambahkan isoamilase sebesar 0,05 \% pada tepung singkong sebagai substitusi $50 \%$ jagung dalam ransum dan memperoleh hasil yang belum mendekati rasio amilosa /amilopektin pada jagung. Hal ini memberikan dugaan baru, yakni usaha menyamakan rasio amilosa dan amilopektin tepung singkong dengan jagung dapat dilakukan dengan peningkatan level penggunaan isoamilase hingga $0,14 \%$, sehingga suplementasi isoamilase pada pakan broiler dapat meningkatkan produktivitas ayam broiler (Huang, 2014). Peningkatan jumlah rantai cabang yang terpotong pada amilopektin diharapkan dapat meningkatkan kandungan amilosa. Dengan demikian dapat meningkatkan ketersediaan nutrien dan meningkatkan produktivitas ayam broiler. Penelitian ini bertujuan mengkaji pengaruh pemberian tepung singkong yang ditambahkan isoamilase sebagai pengganti jagung dalam pakan terhadap performa ayam broiler.

\section{METODE}

\section{Bahan dan Alat}

Bahan yang digunakan selama penelitian meliputi DOC broiler jantan 150 ekor, isoamilase (food grade), singkong tanpa kulit dan telah dikeringkan atau biasa disebut gaplek yang diperoleh dari perkebunan di sekitar Jawa Barat, jagung, bungkil kedelai, meat bone meal, corn gluten meal, crude palm oil, $\mathrm{CaCO}_{3}$, Dikalsium fosfat

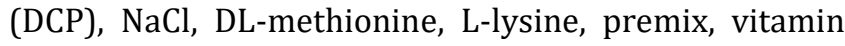
dan vaksin. Alat yang digunakan berupa peralatan kandang, inkubator dan oven $105^{\circ} \mathrm{C}$.

\section{Metode Penelitian}

Rancangan yang digunakan adalah rancangan acak lengkap dengan 3 perlakuan. Masing-masing perlakuan diulang sebanyak 5 kali dan setiap satuan percobaan diisi 10 ekor DOC broiler jantan yang ditempatkan secara acak. Perlakuan diberikan mulai umur 1-35 hari untuk melihat pengaruhnya terhadap performa ayam. Perlakuan yaitu P0: 50\% jagung dalam ransum (kontrol); P1: Substitusi 50\% jagung dengan tepung singkong; P2: Substitusi $50 \%$ jagung dengan tepung singkong yang ditambahkan $0,14 \%$ isoamilase. Formulasi ransum masing-masing perlakuan dapat dilihat pada Tabel 1 . Data yang diperoleh dianalisis menggunakan sidik ragam (ANOVA) dan jika berbeda nyata $(\mathrm{p}<0,05)$ data diuji lanjut Duncan.

\section{Pengukuran Performa Ayam Broiler}

Performa ayam broiler yang diukur selama 35 hari, yaitu konsumsi pakan (g ekor ${ }^{-1}$ ) diperoleh dengan menghitung selisih pemberian pakan dengan sisa pakan dibagi dengan jumlah ayam yang berada dalam satu sekat. Bobot badan (g ekor-1) diperoleh dengan menimbang ayam pada akhir pemeliharaan dan dihitung rataratanya. Pertambahan bobot badan (g ekor-1) diperoleh dari hasil perhitungan antara bobot badan akhir dikurangi bobot badan awal. Bobot badan diukur satu minggu sekali. Konversi pakan diperoleh dengan menghitung perbandingan rata-rata konsumsi pakan dibagi dengan rata-rata pertambahan bobot badan. Mortalitas dihitung dengan membagi jumlah ayam mati dengan jumlah ayam total kemudian dikali 100\%. Income over feed and chick cost (IOFCC) diperoleh dengan cara menghitung selisih total penerimaan dengan total biaya DOC dan pakan yang digunakan selama pemeliharaan 
Tabel 1 Formulasi ransum dan perhitungan kandungan nutrien

\begin{tabular}{|c|c|c|c|c|c|c|}
\hline \multirow{2}{*}{ Bahan pakan (\%) } & \multicolumn{3}{|c|}{ Starter (1-21 hari) } & \multicolumn{3}{|c|}{ Finisher (22-35 hari) } \\
\hline & $\mathrm{PO}$ & $\mathrm{P} 1$ & $\mathrm{P} 2$ & PO & P1 & $\mathrm{P} 2$ \\
\hline Jagung & 55,00 & 27,50 & 27,50 & 55,00 & 27,50 & 27,50 \\
\hline Tepung singkong & 0,00 & 27,50 & 0,00 & 0,00 & 27,50 & 0,00 \\
\hline Tepung singkong + isoamilase & 0,00 & 0,00 & 27,50 & 0,00 & 0,00 & 27,50 \\
\hline Bungkil kedelai & 28,00 & 28,00 & 28,00 & 27,35 & 27,35 & 27,35 \\
\hline Corn gluten meal & 9,59 & 9,66 & 9,66 & 6,42 & 7,42 & 7,42 \\
\hline Meat bone meal & 2,00 & 2,00 & 2,00 & 2,82 & 2,82 & 2,82 \\
\hline Crude palm oil & 1,65 & 1,70 & 1,70 & 4,32 & 4,63 & 4,63 \\
\hline $\mathrm{CaCO}_{3}$ & 0,24 & 0,07 & 0,07 & 0,25 & 0,05 & 0,05 \\
\hline DCP & 2,46 & 2,49 & 2,49 & 2,90 & 1,85 & 1,85 \\
\hline $\mathrm{NaCl}$ & 0,07 & 0,09 & 0,09 & 0,04 & 0,03 & 0,03 \\
\hline L-Lysin & 0,27 & 0,30 & 0,30 & 0,20 & 0,17 & 0,17 \\
\hline DL-Methionine & 0,22 & 0,19 & 0,19 & 0,20 & 0,18 & 0,18 \\
\hline Premix & 0,50 & 0,50 & 0,50 & 0,50 & 0,50 & 0,50 \\
\hline Total (\%) & 100,00 & 100,00 & 100,00 & 100,00 & 100,00 & 100,00 \\
\hline \multicolumn{7}{|l|}{ Kandungan nutrien } \\
\hline Bahan kering (\%) & 87,99 & 88,07 & 88,07 & 85,72 & 88,23 & 88,23 \\
\hline Abu (\%) & 5,61 & 5,98 & 5,98 & 5,31 & 5,52 & 5,52 \\
\hline Protein kasar (\%) & 23,04 & 23,00 & 23,00 & 21,50 & 21,50 & 21,50 \\
\hline Lemak kasar (\%) & 4,29 & 3,59 & 3,59 & 6,70 & 6,50 & 6,50 \\
\hline Serat kasar (\%) & 2,41 & 3,12 & 3,12 & 2,29 & 3,08 & 3,08 \\
\hline Energi metabolis (Kkal kg-1) & $3.005,00$ & $3.000,00$ & $3.000,00$ & $3.150,00$ & $3.150,00$ & $3.150,00$ \\
\hline $\mathrm{Ca}(\%)$ & 0,96 & 0,96 & 0,96 & 0,87 & 0,87 & 0,87 \\
\hline P total (\%) & 0,78 & 0,75 & 0,75 & 0,72 & 0,70 & 0,70 \\
\hline P available & 0,48 & 0,48 & 0,48 & 0,44 & 0,44 & 0,44 \\
\hline Lysine (\%) & 1,44 & 1,44 & 1,44 & 1,29 & 1,29 & 1,29 \\
\hline Methionine (\%) & 0,56 & 0,56 & 0,56 & 0,51 & 0,51 & 0,51 \\
\hline $\mathrm{Na}(\%)$ & 0,23 & 0,22 & 0,22 & 0,17 & 0,17 & 0,17 \\
\hline
\end{tabular}

P0: 50\% jagung dalam ransum (kontrol), P1: Substitusi 50\% jagung dengan tepung singkong, P2: Substitusi50\% jagung dengan tepung singkong yang ditambahkan $0,14 \%$ isoamilase

ternak hingga panen. Nilai IOFCC dapat diperoleh dengan menggunakan rumus:

Keterangan:

$$
\mathrm{IOFCC}=\mathrm{B}-(\mathrm{A}+\mathrm{c})
$$

$$
\begin{aligned}
& A=\text { konsumsi (a) } \mathrm{x} \text { harga pakan }(\mathrm{b}) \\
& \mathrm{B}=\text { bobot badan akhir }(\mathrm{d}) \mathrm{x} \text { harga ayam hidup }(\mathrm{e}) \\
& \mathrm{C}=\text { harga DOC }
\end{aligned}
$$

\section{HASIL DAN PEMBAHASAN}

\section{Bobot Badan}

Perlakuan tidak nyata $(\mathrm{p}>0,05)$ mempengaruhi bobot badan akhir (Tabel 2). Hasil yang diperoleh setiap perlakuan berkisar 1497,39- 1610,83 g ekor-1. Nilai ini lebih rendah dari acuan Aviagen (2018), broiler strain Ross yang dipelihara selama 35 hari memiliki bobot badan sebesar 2235 g ekor $^{-1}$. Hasil perlakuan pakan yang tidak signifikan mempengaruhi bobot badan sesuai dengan Huang (2014) yang menyatakan bahwa penambahan 300 dan $600 \mathrm{U} \mathrm{kg}^{-1} \alpha-1,6$ isoamilase dapat mengimbangi bobot badan akhir ayam yang mendapat perlakuan kontrol. Hal ini membuktikan bahwa pemberian pakan tepung singkong yang ditambahkan isoamilase berdampak pada pemotongan rantai $\alpha-1,6$ dalam amilopektin menjadi amilosa dan meningkatkan gula pereduksi sehingga ketersediaan amilosa dalam pakan mendekati kontrol dan berdampak pada bobot badan akhir yang sama dengan kontrol.

\section{Pertambahan Bobot Badan}

Perlakuan pakan tidak signifikan mempengaruhi pertambahan bobot badan (Tabel 2). Hasil yang sama diperoleh karena konsumsi pakan semua perlakuan selama pemeliharaan tidak signifikan. Pertambahan bobot badan (PBB) ayam yang dipelihara selama 35 hari diperoleh angka 1454,95- $1610 \mathrm{~g}$ ekor-1. Nilai pertambahan bobot badan memiliki pola yang mengikuti konsumsi pakan (Koni et al. 2013). Nilai PBB yang rendah biasanya mengikuti nilai konsumsi yang rendah. Selain itu, nilai PBB yang tidak signifikan juga menggambarkan bahwa kualitas nutrien ransum mengandung tepung singkong baik tanpa maupun dengan penambahan enzim isoamilase adalah sama dengan ransum kontrol (mengandung jagung). Penambahan enzim isoamilase pada tepung singkong menyebabkan peningkatan jumlah rantai cabang yang terpotong pada amilopektin, sehingga diharapkan dapat meningkatkan kandungan amilosa. Dengan demikian dapat meningkatkan ketersediaan nutrien dan meningkatkan pertambahan bobot badan. 
Tabel 2 Performa ayam broiler selama pemeliharaan

\begin{tabular}{|c|c|c|c|c|}
\hline \multirow{2}{*}{ Peubah } & \multicolumn{3}{|c|}{ Perlakuan } & \multirow{2}{*}{$P$ value } \\
\hline & P0 & P1 & $\mathrm{P} 2$ & \\
\hline Bobot Badan DOC (gram ekor ${ }^{-1}$ ) & $42,54 \pm 0,57$ & $43,08 \pm 1,40$ & $42,44 \pm 0,84$ & 0,569 \\
\hline Bobot Badan Akhir (gram ekor-1) & $1538,11 \pm 93,82$ & $1610,83 \pm 108,52$ & $1497,39 \pm 90,43$ & 0,220 \\
\hline $\begin{array}{l}\text { Pertambahan Bobot Badan (gram } \\
\text { ekor }^{-1} \text { ) }\end{array}$ & $1495,57 \pm 93,70$ & $1567,75 \pm 107,58$ & $1454,95 \pm 89,83$ & 0,220 \\
\hline Konsumsi (gram ekor-1) & $2828,17 \pm 124,87$ & $2949,54 \pm 137,22$ & $2843,45 \pm 66,73$ & 0,226 \\
\hline Konversi Pakan & $1,89 \pm 0,13$ & $1,88 \pm 0,11$ & $1,96 \pm 0,15$ & 0,620 \\
\hline Mortalitas (\%) & 0,67 & 0 & 2 & \\
\hline
\end{tabular}

P0: 50\% jagung dalam ransum (kontrol), P1: Substitusi 50\% jagung dengan tepung singkong, P2: Substitusi50\% jagung dengan tepung singkong yang ditambahkan $0,14 \%$ isoamilase

\section{Konsumsi Pakan}

Konsumsi pakan kumulatif ayam penelitian selama pemeliharaan tidak signifikan dipengaruhi perlakuan pakan, namun ada tendensi $(\mathrm{p}<0,226)$ peningkatan konsumsi untuk ayam yang mendapat perlakuan tepung singkong sebesar 121,37 gram dibandingkan dengan kontrol. Hasil ini disebabkan substitusi 50\% jagung dengan tepung singkong dalam pakan menyebabkan laju alir pakan dalam saluran pencernaan lebih cepat, sehingga konsumsi semakin meningkat (Puspita, 2019). Semakin besar penggunaan tepung singkong dalam pakan, maka kandungan amilopektin dalam ransum juga akan meningkat. Komponen serat yang tidak larut dalam air menyebabkan laju alir pakan yang lebih cepat (Langhout, 1998). Amilopektin singkong memiliki panjang rantai yang relatif panjang dan menyebabkan pati singkong sulit dicerna oleh unggas. Berat molekul amilopektin lebih tinggi yakni $10^{4}-10^{6} \mathrm{kDa}$, sedangkan amilosa sekitar $100 \mathrm{kDa}$ (Rakshit \& Wang, 2016). Amilopektin memiliki rantai cabang cenderung kurang larut dalam air. Struktur kimia amilopektin dengan rantai relatif panjang menyebabkan pati singkong sulit dicerna oleh unggas (Kiatponglarp \& Tongta, 2007).

\section{Konversi Pakan}

Perlakuan pakan tidak signifikan mempengaruhi konversi pakan kumulatif seperti ditunjukkan pada Tabel 2. Nilai konversi kumulatif penelitian ini lebih besar dari standar broiler strain Ross oleh Aviagen (2018), dan sama dengan hasil Huang (2014) yang menyatakan bahwa 300 dan $600 \mathrm{U} \mathrm{kg}^{-1} \alpha-1,6$ isoamilase dapat menghasilkan konversi pakan lebih tinggi daripada kontrol. Yuan et al. (2017) juga membuktikan bahwa penambahan enzim 200 dan $400 \mathrm{U} \mathrm{kg}^{-1} \alpha-1,6$ menyebabkan peningkatan konversi ransum. Peningkatan nilai konversi ransum diperoleh karena daya cerna nutrien yang menurun seiring dengan peningkatan level penggunaan isoamilase. Hal ini juga membuktikan bahwa efek penambahan enzim mungkin tidak selalu bermanfaat, dan perbedaan sumber dan konsentrasi sebenarnya dapat menyebabkan efek negatif pada ayam broiler.

\section{Mortalitas}

Mortalitas kumulatif sebesar 2,67\% dan tidak dipengaruhi oleh perlakuan pakan. Ayam yang mati terjadi pada periode starter dan masih dalam kondisi normal. Menurut Fitro et al. (2018), kematian biasanya terjadi pada fase starter dan pemeliharaan dikatakan berhasil apabila kematian pada periode ini kurang dari $5 \%$. Kematian dipengaruhi oleh penyakit sudden death syndrome karena diketahui ciri fisik pada saat ayam mati, yakni kematian yang tiba-tiba dan dalam posisi terlentang. Sudden death syndrome disebabkan oleh metabolic disorder (Siddiqui et al. 2009).

\section{Income Over Feed Cost}

Nilai income over feed and chick cost (IOFCC) penelitian ini disajikan pada Tabel 3. Ayam yang diberi perlakuan substitusi $50 \%$ tepung singkong memiliki nilai IOFCC yang lebih besar dibandingkan dengan penambahan enzim dan kontrol. Menurut Toukourou et al. (2017), penggunaan tepung singkong sebagai pengganti jagung mampu menekan biaya pakan ayam broiler. Komponen yang mempengaruhi biaya produksi adalah konsumsi dan harga pakan (Thirumalaisamy et al. 2016), sedangkan komponen yang mempengaruhi pendapatan adalah bobot badan akhir, harga pakan, harga DOC dan harga ayam. Ayam dengan perlakuan kontrol memiliki nilai IOFCC yang terendah dari perlakuan lainnya. Hal ini karena total biaya pakan tertinggi terdapat pada perlakuan $50 \%$ jagung dalam ransum (kontrol) sebesar Rp 18.664,80.

\section{SIMPULAN}

Pemberian tepung singkong tanpa dan dengan penambahan $0,14 \%$ isoamilase mampu menghasilkan performa yang sama seperti ayam broiler yang diberi pakan jagung dalam ransum selama lima minggu penelitian.

\section{DAFTAR PUSTAKA}

Aldillah R. 2018. Dinamika perubahan harga padi jagung kedelai serta implikasinya terhadap pendapatan usaha tani. Forum Penelitian Agro Ekonomi. 36 (1): 23-44.

Aviagen. 2018. Ross broiler management handbook [internet]. [diacu 2020 Maret 05]. Tersedia dari: http://eu.aviagen.com/techcenter/download/18/Ross-BroilerHandbook2018EN.pdf.

Dei HK. 2017. Assesment of Maize (Zea mays) as Feed Resource for Poultry. In Poultry Science. Zagreb (HR): IntechOpen. 
Fitro R, Sudrajat D \& Dihansih, E. 2018. Performa ayam pedaging yang diberi ransum komersial mengandung tepung ampas kurma sebagai pengganti jagung. Jurnal Peternakan Nusantara. 1 (1) 2442-2541.

Freddy IM. \& Gupta EK. 2018. Penguatan kebijkan ketahanan pangan: reformasi mekanisme penyaluran benih jagung hibrida. Journal on Socio-Economic of Agriculture and Agribusiness. 12 (1): 15-38.

Huang Z. 2014. Effects and mechanism of isoamylase additive on growth performance in broilers. Siliao Gongye. 35 (6): 1-5.

[Kementan] Kementerian Pertanian. 2018. Data lima tahun terakhir. https://www.pertanian.go.id/ Data5tahun/TPATAP-2017(pdf), diakses pada tanggal 05 Juni 2020.

Kiatponglarp W \& Tongta S. 2007. Structural and physical properties of debranched tapioca starch. Suranaree Journal Science Technology. 14 (2): 195-204.

Koni TNI, Paga A \& Jehemat A. 2013. Performa produksi broiler yang diberi ransum mengandung biji asam hasil fermentasi dengan rag tempe (Rhyzopus oligosporus). Jurnal Ilmu Ternak. 13 (1): 13-16.
Langhout DJ. 1998. The role of intestinal flora as affected by non-starch polysaccharides in broiler chicks [tesis]. Wageningen (DE): Wageningen University.

Puspita PS. 2019. Penggunaan isoamilase pada tepung singkong dan pengaruhnya terhadap produktivitas ayam broiler [tesis]. Bogor (ID): Institut Pertanian Bogor.

Siddiqui MF, Patil MS, Khan KM \& Khan LA. 2009. Sudden death syndrome - an overview. Veteriner World. 2 (11): 444-447.

Thirumalaisamy G, Muralidharan J, Senthilkumar S, Sayee RH \& Priyadharsini M. 2016. Cost-effective feeding of poultry. International Journal of Environmental Science and Technology. 5 (6): 3997-4005.

Toukourou Y, Issifou DS, Alkoiret IT, Paraiso A \& Mensah GA. 2017. The effect of feeding restriction with cassava flour on carcass composition of broilers. Journal of Agriculture and Rural Development in the Tropics and Subtropics. 118 (2): 259-267.

Yuan J, Xingyu W, Dafei Y, Maofei W, Xiaonan Y, Zhao L \& Yuming G. 2017. Effect of different amylases on the utilization of cornstarch in broiler chickens. Poultry Science. 96 (5): 1139-1148. 